\title{
Pengembangan Buku Pendidikan Seksual Anak Usia 1-3 Tahun
}

\author{
Gokma Nafita Tampubolon $^{1 凶}{ }^{\circledR}$, Yuliani Nurani ${ }^{2}$, Sri Martini Meilani ${ }^{3}$ \\ Pendidikan Anak Usia Dini, Universitas Negeri Jakarta
}

\begin{abstract}
Abstrak
Banyak orang tua yang belum terbiasa bagaimana memberikan pendidikan seksual sejak dini. Padahal perkembangan seksual telah dimulai sejak anak lahir. Penelitian ini bertujuan mengembangkan buku pendidikan seksual bagi anak usia 1-3 tahun. Buku dikembangkan menggunakan tahap pengembangan produk Derek Rowntree dan disusun berdasarkan perkembangan seksual anak usia 1-3 tahun serta materi-materi pendidikan seksual yang sesuai dengan usia anak. Penelitian dilakukan selama enam bulan sejak Januari 2019. Uji efektivitas buku dilakukan dengan metode eksperimen one-group pretest-posttest. Responden dalam penelitian sebanyak 27 orang. Terdapat prosentasi peningkatan setelah diberikan perlakuan sebesar 34.7\%. Diperoleh nilai $t_{\text {hitung }}$ sebesar 7,407 dengan uji satu sisi pada taraf signifikan 0.05 dengan $n-1=26$ adalah 2.05. Maka dapat disimpulkan bahwa $t_{\text {hitung }}>t_{\text {tabel }}$ yaitu $7.407>$ 2.05 yang berarti terdapat perubahan yang signifikan antara skor pretest dengan posttest. Dapat disimpulkan bahwa terdapat peningkatan pengetahuan, sikap dan keterampilan orang tua tentang pendidikan seksual anak usia 1-3 tahun melalui buku pendidikan seksual anak usia 1-3 tahun.
\end{abstract}

Kata Kunci: pendidikan seksual; seksualitas; anak usia dini

\begin{abstract}
Many parents are do not understand how to provide sexual education early. Though sexual development has begun since the child was born. This study aims to develop a sexual education book for children aged 1-3 years. The book was using the Derek Rowntree product development stage and was compiled based on the sexual development of children aged 1-3 years and sexual education materials that were appropriate for the age of the child. The study was conducted for six months from January 2019. The effectiveness of the book was carried out by the one-group pretest-posttest experimental method. Respondents in the study were 27 people. There is a percentage increase after being given a treatment of $34.7 \%$. Obtained a value of 7.407 with a one-sided test at a significant level of 0.05 with $n-1=26$ is 2.05 . Then it can be concluded that $\mathrm{t}$-count $>\mathrm{t}$-table that is $7.407>2.05$ which means that there is a significant change between the pretest score and posttest. It can be concluded that there is an increase in knowledge, attitudes and skills of parents about sexual education of children aged 1-3 years through sexual education books for children aged 1-3 years.
\end{abstract}

Keywords: sexual education; sexuality; early childhood

Copyright (c) 2019 Gokma Nafita Tampubolon, Yuliani Nurani, Sri Martini Meilani

$\square$ Corresponding author :

Address : Jalan Salak 2 No 7. Kupang

Email : gokma.tampubolon@yahoo.co.id

ISSN 2356-1327 (Media Cetak)

ISSN 2549-8959 (Media Online) 


\section{PENDAHULUAN}

Seorang anak sewajarnya akan bertumbuh dan berkembang seusia dengan usianya. Pertumbuhan seorang anak paling terlihat adalah fisiknya, anak semakin bertambah berat dan tinggi badannya. Kemudian, anak mulai merangkak, berjalan, mengeluarkan kata pertama, berbicara lalu mampu bernyanyi, anak mulai bersosialisasi dan membangun pertemanan serta mengembangkan kemampuan kognitif. Orang tua akan sangat bangga untuk membicarakan hal ini. Namun berbeda dengan perkembangan seksual yang sering terlupakan oleh orang tua (Ballard \& Gross, 2009; Nadar, 2017; Sciaraffa \& Randolph, 2011) dimana orang tua tidak memberi perhatian secara sadar pada perkembangan tersebut. Faktanya bahwa orang tua selalu bersentuhan dengan bagian sensitif ini sejak anak lahir, seperti saat orang tua memandikan bayi, menyusui, mengganti popok, dan membersihkan bayi.

Pembicaraan

mengenai

perkembangan seksual anak masihlah tabu dan kontradiksi (Davies \& Robinson, 2010). Beberapa orang tua merasa tidak nyaman membicarakan hal tersebut (Turnbull, Wersch, \& Schaik, 2008). Dalam penelitian yang dilakukan Tampubolon, Nurani, \& Meilani (2019), mayoritas orang tua yang memiliki anak usia 1-3 tahun memiliki persepsi yang salah mengenai pendidikan seksual. Orang tua berpersepsi bahwa pendidikan seksual hanya mengajarkan tentang alat reproduksi pada anak serta tidak benar menggunakan istilah penis atau vagina pada anak-anak. Hal ini sejalan dengan temuan Ballard \& Gross (2009) bahwa orang tua masih beranggapan pendidikan seks hanya terkait dengan aspek biologis.

Orang tua lalu berusaha mengalihkan pembicaraan tentang seksualitas dengan anak (Anggraeni, 2014; Davies \& Robinson, 2010). Hal ini dikarenakan ketidakmampuan orang tua menjelaskan pertanyaan anak, sehingga orang tua memberikan jawaban yang sesat dan salah (Martin, Riazi, Firoozi, \& Nasiri, 2018). Hal ini membuat pemahaman anak mengenai seksualitasnya menjadi keliru. Orang tua juga beranggapan bahwa anak masih terlalu kecil untuk belajar mengenai pendidikan seksual (Sugiasih, 2011) terutama orang tua yang memiliki anak usia 0-3 tahun (Ballard \& Gross, 2009). Orang tua bingung materi pendidikan seksual apa yang pantas diberikan kepada anak usia tersebut. Ini dikarenakan konsep pendidikan seksual yang keliru tadi.

Pendidikan seksual harusnya membantu anak memahami perkembangan seksualitasnya dengan benar sehingga dapat membangun gambaran yang baik akan tubuh mereka (Sciaraffa \& Randolph, 2011). Respon orang tua terhadap perkembangan tersebut akan berpengaruh pada gambaran seksualitas anak. Jika orang tua membangun gambaran yang negatif, seperti alat kelamin adalah sesuatu yang memalukan maka gambaran anakpun akan negatif terhadap alat kelaminnya. Sama halnya dengan pengetahuan lain, anak perlu mengetahui istilah yang tepat dalam menyebutkan alat kelaminnya.

Selain itu pendidikan seksual menjadi bagian dari upaya pencegahan anak tereksploitasi terhadap kekerasan seksual. Kasus kekerasan seksual anak (KSA) semakin banyak ditemui. Komisi Nasional Perlindungan Anak menetapkan tahun 2016 sebagai kondisi Darurat Nasional Kejahatan Seksual terhadap anak. Semakin banyaknya ancaman bagi anak membuat orang tua harus mengambil langkah strategis dan bijak untuk melindungi anak. Keluarga seharusnya menjadi tempat perlindungan pertama bagi anak. Orang tua dapat memberikan pendidikan seksual sedini mungkin melalui kata dan kalimat sederhana namun tepat dan tidak vulgar. 
Komunikasi yang baik antara anak dengan orang tua juga dipercaya mampu melindungi anak dari kejahatan seksual. Menghargai naluri anak yang tidak mau bersalaman dengan seseorang akan membuat anak belajar mempertahankan dan menjaga apa yang dimilikinya (Probosiwi \& Bahransyaf, 2015).

Sayangnya, kegiatan preventif masih banyak dilakukan di sekolah. Orang tua berharap pihak sekolah dapat melengkapi dan melindungi anak dari kekerasan seksual(Walsh \& Brandon, 2012). Tetapi, peran pendidik utama adalah keluarga. Kebanyakan anak memulai sekolah di umur 3 atau 5 tahun. Sehingga anak dalam rentang usia 0-3 tahun jarang mendapatkan manfaat dari program preventif tersebut. Anak usia 0-3 tahun kurang memahami mengenai kekerasan, tidak dapat melaporkan kejadian jika mengalaminya serta sulit melindungi dirinya jika mengalami situasi yang berbahaya. Namun, anak usia 0-3 tahun memiliki resiko menjadi korban juga. Peran orang tua penting untuk melindungi anak.

Seksualitas anak adalah sesuatu yang intim dan sensitif bagi anak. Ini menyentuh daerah pribadi anak. Oleh karena itu, sebaiknya orang tualah yang membangun komunikasi efektif dan mendidik sendiri anaknya tentang pendidikan seksual. Orang tua yang memiliki kedekatan dengan anak akan memudahkan mereka mengetahui batas informasi yang perlu disampaikan. Selain itu, orang tua tidak perlu menunggu sampai anak memasuki usia sekolah untuk mendapatkan pengetahuan tersebut. Orang tua dapat memulainya sendiri sejak anak lahir.

Banyak orang tua yang tidak mendapatkan pendidikan seksual sewaktu kecil (Amaliyah \& Nuqul, 2017; Ballard \& Gross, 2009), sehingga orang tua tidak mengerti bagaimana memulainya. Orang tua tidak memiliki pengetahuan dan keterampilan dalam memberikan pendidikan seksual (Martin et al., 2018; Turnbull et al., 2008). Orang tua tidak percaya diri memberikan pendidikan seksual kepada anak. Penelitian oleh Martin et al., (2018) membuktikan bahwa ibu yang diberikan pendidikan dan pelatihan pendidikan seks anak akan meningkat pengetahuan dan keterampilannya. Maka, orang tua perlu dibekali pengetahuan mengenai perkembangan seksual anak, memiliki keterampilan komunikasi yang efektif, memiliki kedekatan yang baik dengan anak serta mendidik anak dengan moral yang berlaku umum di masyarakat dan nilai-nilai yang dianut oleh masingmasing keluarga.

Oleh karena itu, perlu mengembangkan buku pendidikan seksual anak usia 1-3 tahun untuk menyiapkan orang tua dalam menghadapi perkembangan seksual, perilaku seksual dan pertanyaan anak mengenai seksualitasnya. Pendidikan seksual tidak dapat dipisahkan dari nilainilai agama dan moral yang dianut oleh keluarga dimana anak tumbuh karena nilainilai itu yang akan menjadi landasan anak dalam berinteraksi sosial. Tujuan dari penelitian ini adalah mengembangkan Buku Pendidikan Seksual Anak Usia 1-3 Tahun sebagai Panduan bagi Orang Tua.

Hal-hal yang dapat diajarkan kepada anak usia 1-3 tahun mengenai pendidikan seksual disesuaikan dengan perkembangan anak. Sejak anak lahir sampai 18 bulan, anak mengembangkan pengetahuan akan identitas gender, dapat membedakan antara laki-laki dan perempuan. Anak juga mengeksplorasi tubuh mereka termasuk alat kelamin. Orang tua dapat memperhatikan hal ini saat mengganti popok anak, anak akan menyentuh alat kelaminnya sendiri. Ini adalah perkembangan yang wajar (Sciaraffa \& Randolph, 2011). Dalam masa ini, bayi dan batita mungkin akan melakukan self-pleasuring karena 
memberikan ketenangan bagi mereka. Selfpleasuring didapat dari kedekatan intim anak dengan orang tua. Anak akan menikmati saat-saat dipeluk, didekap dan dicium. Dalam rentang usia ini, anak juga akan mulai membentuk gambaran yang positif atau negatif mengenai tubuh, bagian mana saja yang dapat dan tidak dapat disentuh serta sentuhan-sentuhan apa yang boleh dan tidak boleh (Sciaraffa \& Randolph, 2011).

Dalam rentang usia 18-36 bulan, anak sedang melatih menggunakan toilet, anak akan mulai mempelajari bagian-bagian tubuh di sekitar area alat kelamin. Karena anak berada dalam rentang usia yang sedang mengembangkan kosakata, maka penggunaan istilah-istilah alat kelamin yang tepat akan memberikan konsep yang benar bagi anak (Sciaraffa \& Randolph, 2011).

Pada usia 3 tahun, anak-anak akan mulai tertarik tentang perbedaan berkemih antara anak laki-laki dan perempuan. Anak perempuan mungkin akan mencoba berkemih sambil berdiri atau sebaliknya. Anak juga menjadi sangat penuh dengan kasih sayang, mereka senang memeluk dan mencium orang tuanya, bahkan melamar orang tua yang berjenis kelamin berbeda (Hyde \& Delamater, 2017). Anak juga menunjukkan perilaku-perilaku mencium, memeluk, menepuk, membelai dan menatap anak lain, perilaku yang menjadi bagian keintiman erotis di jenjang kehidupan berikutnya (Hyde \& Delamater, 2017). Disimpulkan oleh Kellogg (2010), kebanyakan anak usia 2-5 tahun akan menunjukkan perilaku seperti menyentuh alat kelamin di rumah dan tempat umum; menyentuh payudara; berada terlalu dekat dengan orang lain serta berusaha melihat orang yang sedang telanjang.

Buku yang telah dikembangkan berdasarkan perkembangan seksual anak tersebut akan diuji cobakan kepada orangtua sebagai pembaca untuk melihat efektivitas penggunaan buku apakah berhasil meningkatkan pengetahuan, sikap dan keterampilan orang tua terhadap pendidikan seksual terhadap anak usia 1-3 tahun.

\section{METODOLOGI}

Metodologi dalam penelitian ini adalah penelitian dan pengembangan (research and development) menggunakan tahap pengembangan oleh Derek Rowntree. Pendekatan ini dipilih karena penelitian ini bertujuan untuk mengembangkan sebuah produk pembelajaran berupa buku cetak dan model pengembangan yang cocok untuk mencapai tujuan tersebut adalah model Rowntree (1994). Dengan tahapan prosesnya yaitu Tahap 1: Perencanaan; Tahap 2: Persiapan menulis; dan Tahap 3: Penulisan dan Penyuntingan.

Tahap perencanaan adalah tahap kegiatan mendesain dan merencanakan produk yang akan dikembangkan. Pada tahap perencanaan dilakukan identifikasi dan analisis karakteristik para orang tua yang akan menjadi pemakai buku. Hasil penelitian pendahuluan, diperoleh informasi tentang karakteristik orang tua yaitu kebanyakan orang tua berusia 20-40 tahun dengan tingkat pendidikan heterogen dari SMP sampai S2 serta pengetahuan dan sikap terhadap pendidikan seksual beragam dari semua level (baik, cukup dan kurang).

Adapun tujuan umum dari buku ini adalah orang tua yang memiliki anak usia 1-3 tahun akan mampu memberikan pendidikan seksual yang baik dan benar kepada anak usia 1-3 tahun, sedangkan tujuan khususnya adalah orang tua mampu mendeskripsikan perkembangan anak usia 1-3 tahun secara umum, mampu mendeskripsikan pendidikan seksual anak usia 1-3 tahun, menunjukkan dukungan terhadap pendidikan seksual anak usia 1-3 tahun serta mampu menerapkan pendidikan seksual anak usia 1-3 tahun di rumah. 
Garis besar isi materi (konten) dalam buku dikembangkan berdasarkan kajian literatur, kajian penelitian terhadap perkembangan anak, perkembangan seksual dan pendidikan seksual anak usia dini. Selain kajian tersebut, dilakukan juga observasi perkembangan seksual anak sejak berusia 1-2,5 tahun. Maka terdapat dua bagian utama dalam konten buku yaitu:

1) Perkembangan anak usia 1-3 tahun secara umum,

2) Pendidikan seksual bagi anak

3) Materi-materi pendidikan seksual bagi anak diantaranya penggunaan istilah yang benar; perbedaan jenis kelamin, pengenalan tubuh; toilet training; privasi; tubuhku berharga; perlindungan diri

Tahap penulisan dan penyuntingan adalah kegiatan membuat dan menulis serta menyunting buku, sehingga buku yang dikembangkan menjadi sebuah produk yang layak pakai. Draft buku diserahkan kepada pakar untuk divalidasi. Adapun pakar adalah pakar media, pakar medis, pakar psikologis dan pakar PAUD. Para pakar memberikan masukan yang menjadi acuan peneliti untuk merevisi buku.

Untuk menguji efektifitas buku maka instrumen pengukuran disusun berdasarkan tujuan khusus dari buku pendidikan seksual anak usia 1-3 tahun. Uji coba dilakukan dua kali yaitu ujicoba face-to-face kepada tiga orang tua dan uji coba lapangan kepada 27 orang tua. Hasil yang didapat dari uji coba menjadi bahan melakukan revisi atau perbaikan.

Tempat penelitian dan pengembangan ini berada di tiga posyandu di Kelurahan Sikumana Kecamatan Maulafa Kota Kupang Provinsi Nusa Tenggara Timur. Uji coba produk awal akan dilakukan kepada tiga orang tua di Posyandu Kamboja 3B dan uji coba lapangan utama dilakukan di Posyandu Kamboja 2A dan Posyandu Kasih.
Data kuantitatif yang sudah diperoleh dari hasil tes dianalisis dengan membandingkan nilai pretest dan nilai posttest orang tua. Tes ini dilakukan untuk melihat apakah terdapat perbedaan nilai secara signifikan mengenai pengetahuan, sikap dan keterampilan orang tua sebelum dan setelah penggunaan buku pendidikan seksual anak usia 1-3 tahun bagi orang tua. Dalam hal ini, perhitungan statistik dilakukan dengan statistik sederhana.

\section{HASIL DAN PEMBAHASAN Validasi Pakar}

Para pakar materi yaitu psikolog anak dan remaja, dokter dan dosen PAUD yang memberikan penilaian terhadap aspekaspek dalam buku yaitu tujuan pembelajaran, kemutakhiran materi dan bahasa. Sedangkan dosen teknologi pendidikan memberikan penilaian terhadap aspek-aspek tampilan, kepraktisan, tulisan dan ilustrasi gambar. Secara keseluruhan para pakar memberikan nilai 3,625 (Baik).

\section{Ujicoba Lapangan Pendahuluan}

Uji coba lapangan pendahuluan dilakukan kepada tiga orang tua dari Posyandu Kamboja. Orang tua yang dipilih

Tabel 1. Hasil Pretest dan Posttest

\begin{tabular}{|l|c|}
\hline Tahap & Nilai Rata-Rata \\
\hline Pretest & 17 \\
\hline Posttest & 23 \\
\hline Peningkatan & 6 \\
\hline $\begin{array}{l}\text { Prosentasi } \\
\text { Peningkatan }\end{array}$ & $\mathbf{3 5 \%}$ \\
\hline
\end{tabular}

masing-masing memiliki tingkat pendidikan SMP, SMA dan Sarjana. Hal ini dilakukan agar memastikan buku dapat dipahami oleh semua orang tua dari tingkat pendidikan 
apapun seperti yang direncanakan. Orang tua memberikan masukan untuk memperbaiki gambar tampilan sampul dan komposisi warna dalam isi buku agar lebih menarik.

\section{Ujicoba Lapangan Utama}

Setelah buku direvisi sesuai saran dari ujicoba pendahuluan, kemudian buku pendidikan seksual anak usia 1-3 tahun diujicoba lapangan. Ujicoba lapangan melibatkan 35 orang tua dari dua Posyandu, namun hanya 27 orang tua saja yang mengikuti proses sampai akhir. Pada ujicoba lapangan terdapat dua uji yang dilakukan yaitu:

\section{Uji Efektivitas Buku}

Untuk mengetahui efektivitas dari buku yang dikembangkan, peneliti memberikan pretest dan posttest kepada orang tua. Pretest dan posttest yang diberikan telah divalidasi isi oleh para pakar. Selain itu soal tes juga telah diujicoba validitas dan reliabilitas kepada sebanyak 50 orang tua.

Pretest diberikan sebelum orang tua membaca buku pendidikan seksual anak usia 1-3 tahun. Kemudian orang tua diberi kesempatan untuk membawa pulang dan membaca buku selama satu minggu. Setelah membaca buku, orang tua diberikan posttest untuk melihat peningkatan nilai tes antara sebelum dan sesudah membaca buku.

Nilai hasil pretest terendah adalah 9 dan nilai tertinggi adalah 26. Nilai hasil posttest terendah adalah 15 dan nilai tertinggi adalah 29. Nilai rata-rata pretest adalah 17 dan nilai rata-rata posttest adalah 23. Dari tabel di atas dapat dilihat bahwa terdapat prosentasi peningkatan skor sebesar $35 \%$ sebelum dan sesudah membaca buku.

Analisis perbedaan rata-rata antara pretest dan posttest dilakukan dengan menggunakan uji-t berpasangan. Analisis ini dilakukan untuk mengetahui ada atau tidaknya perbedaan yang signifikan antara skor pretest dan posttest.

Tabel 2. Hasil perhitungan nilai pretest dan

\begin{tabular}{lllccc}
\multicolumn{6}{c}{ posttest } \\
& $\mathrm{N}$ & $\begin{array}{l}\text { Mea } \\
\mathrm{n}\end{array}$ & $\mathrm{Sd}$ & $\mathrm{t}_{\text {hitung }}$ & $\mathrm{t}_{\text {tabel }}$ \\
\cline { 1 - 3 } Pretest & 2 & 17,1 & & & \\
& 7 & 9 & 4,18 & 7,407 & 2,05 \\
\cline { 1 - 2 } Posttes & 2 & 23,1 & 3 & & \\
$\mathrm{t}$ & 7 & 5 & & & \\
\hline
\end{tabular}

Dari hasil perhitungan tersebut memperoleh nilai $t_{\text {hitung }}$ sebesar 7,407 dengan uji satu sisi pada taraf signifikan 0.05 dengan $\mathrm{n}-1=26$ adalah 2,05. Maka dapat disimpulkan bahwa $t_{\text {hitung }}$ lebih besar dari $t_{\text {tabel }}$ yaitu $7,407>2.05$ yang berarti terdapat perubahan yang signifikan antara skor pretest dengan posttest. Dapat disimpulkan bahwa terdapat peningkatan pengetahuan, sikap dan keterampilan orangtua terhadap pendidikan seksual anak usia 1-3 tahun melalui buku pendidikan seksual anak usia 1-3 tahun di dua Posyandu.

\section{Pembahasan}

Penelitian dan pengembangan buku pendidikan seksual anak usia 1-3 tahun dilakukan karena adanya ketimpangan di lapangan berdasarkan kajian penelitian terdahulu dan kajian literatur sehingga dilakukan penelitian pendahuluan dengan metode survei untuk mendukung pengembangan buku ini. Kemudian dilakukan perencanaan pelaksanaan penelitian, pengembangan produk buku serta uji coba kelayakan dan efektivitas buku. Penelitian dan pengembangan ini menghasilkan model konseptual yang tertuang dalam materi buku, sebuah produk buku pendidikan seksual anak usia 1-3 tahun serta instrumen untuk mengukur 
pengetahuan, sikap dan keterampilan orang tua terhadap pendidikan seksual.

Materi pendidikan seksual yang diberikan didasarkan pada perkembangan seksual anak yang sesuai dengan umur anak. Perilaku seksual yang tidak sesuai dengan usia anak biasanya muncul jika keluarga terlalu terbuka dan tanpa batasan terhadap seksualitas, dimana tidak ada privasi saat anggota keluarga berganti pakaian atau saat mandi ataupun akses terhadap pornografi secara bebas (Kellogg, 2009). Salah satu materi dalam buku membahas mengenai privasi, dimana orangtua melatih anak untuk menghargai anggota keluarga yang sedang mandi atau mengetuk pintu saat ingin masuk ke dalam kamar. Aturan yang diterapkan oleh keluarga soal privasi dapat mengantisipasi perilaku-perilaku seksual yang tidak sesuai dengan usia anak.

Salah satu dasar dalam mengembangkan buku pendidikan seksual adalah nilai agama dan moral yang berlaku di masyarakat. Aturan sosial di satu tempat akan berbeda dengan aturan sosial di tempat lain. Di negara Denmark, dalam institusiinstitusi seperti Tempat Penitipan Anak atau prasekolah, anak-anak tidak diizinkan untuk bermain "dokter-dokteran", telanjang saat berenang, atau diambil fotonya dengan pakaian yang minim (Leander, Larsen, \& Munk, 2018). Berbeda dengan negara Indonesia, masih banyak ditemui anak-anak bertelanjang saat berenang di laut atau sungai. Institusi-institusi PAUD juga masih belum menaruh perhatian terhadap peraturan-peraturan seperti ini. Ini menunjukkan bahwa perhatian terhadap perkembangan dan pendidikan seksual anak usia dini masih kurang.

Dalam tulisan Wurtele \& Kennym (2011), menemukan bahwa tidak ada pencapaian yang signifikan antara temuan penelitian sekitar tahun 1990an dengan tahun 2000an, dimana jumlah anak yang dapat menyebutkan alat kelaminnya dengan benar masih tetap sedikit. Usaha orang tua dalam memberikan pendidikan seksual masih terbatas dan belum optimal. Oleh karena itu, pengembangan buku pendidikan anak usia sedini mungkin dirasa tepat untuk memberikan pencapaian yang lebih baik dan cepat lagi.

Keberhasilan produk buku yang dikembangkan sejalan dengan penelitian oleh Martin \& Torres (2014) dimana setelah orang tua mendapatkan sosialisasi membaca salah satu buku pendidikan seksual populer, menjadi lebih aktif dalam melakukan percakapan mengenai seksualitas dengan anaknya. Hal ini membuktikan bahwa orang tua memerlukan edukasi mengenai pendidikan seksual agar dapat memberikan materi-materi pendidikan seksual yang tepat kepada anak. Dari evaluasi terhadap 44 program intervensi dengan orang tua untuk mempromosikan kesehatan seksual anak ditemukan bahwa intervensi bersama orang tua akan mengubah interaksi orang tua-anak yang kemudian mengubah pengetahuan, sikap dan keterampilan orang dewasa (Wight \& Fullerton, 2013). Perubahan pengetahuan, sikap dan keterampilan orang tua yang juga menjadi tujuan dalam pengembangan buku pendidikan akan memberikan dampak yang positif terhadap hubungan dan interaksi orang tua dan anak.

\section{KESIMPULAN}

Buku yang dikembangkan bertujuan untuk meningkatkan pengetahuan, sikap dan keterampilan orang tua dalam memberikan pendidikan seksual bagi anak berusia 1-3 tahun di rumah masing-masing. Kompetensi pengetahuan yang dimaksud adalah orang tua memiliki pemahaman yang tepat mengenai pentingnya memberikan pendidikan seksual dan cara memberikan pendidikan seksual tersebut. Kompetensi sikap yang dimaksud adalah 
orang tua mendukung dan terbuka dengan pelaksanaan pendidikan seksual di dalam rumah masing-masing. Kompetensi keterampilan yang dimaksud adalah orang tua terampil dalam memberikan pendidikan seksual kepada anak sejak dini. Keterampilan ini bisa didapat jika orang tua mau memulai untuk menerapkannya di dalam keluarga masing-masing. Terdapat peningkatan skor pengetahuan, sikap dan keterampilan orang tua setelah membaca buku pendidikan seksual tersebut. Artinya tujuan pembelajaran dalam buku tersebut telah tercapai dan buku tersebut efektif.

\section{UCAPAN TERIMA KASIH}

Terimakasih kepada pihak Puskesmas Sikumana dan Posyandu-posyandu yang telah ikut serta dalam penelitian ini dan kepada LPDP yang telah membiayai penelitian ini.

\section{DAFTAR PUSTAKA}

Amaliyah, S., \& Nuqul, F. L. (2017). Eksplorasi Persepsi Ibu tentang Pendidikan Seks untuk Anak. Psymphatic: Jurnal Imliah Psikologi, 4(2), 157-166. https://doi.org/10.15575/psy.v4i2.175 8

Anggraeni, D. W. (2014). Komunikasi untuk Pendidikan Seks pada Anak Usia Dini. Interaksi Online, 8(4).

Aprilia, A. (2015). Perilaku Ibu Dalam Memberikan Pendidikan Seks Usia Dini pada Anak Prasekolah. Jurnal Kesehatan Masyarakat, 3(1).

As'ari, F., Prasetya, H., \& Sanjaya, R. (2017). Children Safety: Education Game for Childs Sex Education. SISFORMA, 3(2), 44. https://doi.org/10.24167/sisforma.v3i 2.844

Astuti, S. W. (2017). Pendidikan Seks pada Anak Taman Kanak-kanak Melalui
Metode Permainan Ular Tangga "Aku Anak Berani” (Studi Deskripsi Komunikasi Interpersonal Anak dalam Bermain Ular Tangga "Aku Anak Berani”). Promedia, (2), 236251.

Ballard, S. M., \& Gross, K. H. (2009). Exploring Parental Perspectives on Parent-Child Sexual Communication Exploring Parental Perspectives. American Journal of Sexuality Education, 4(November 2014), 3741.

https://doi.org/10.1080/15546120902 733141

Collin-vézina, D., Daigneault, I., \& Hébert, M. (2013). Lessons learned from child sexual abuse research : prevalence, outcomes, and preventive strategies. Child and Adolescent Psychiatry and Mental Health, 7(22), 1-9. Retrieved from http://www.capmh.com/content/7/1/2 2

Davies, C., \& Robinson, K. (2010). Hatching Babies and Stork Deliveries : risk and regulation in the construction of children' $\mathrm{s}$ sexual knowledge. Contemporary Issues in Early Childhood, 11(3), 249-262. https://doi.org/hhtp://dx.doi.org/10.23 04/ciec.2010.11.3.249

Deblinger, E., Thakkar-Kolar, R. R., Berry, E. J., \& Schroeder, C. M. (2009). Caregivers' Efforts to Educate Their Children About Child Sexual Abuse:

A Replication Study. Child Maltreatment, 15(1), 91-100. https://doi.org/10.1177/10775595093 37408

European Expert Group of Education Sexuality. (2015). Sexuality education - what is it? Sexuality Education, $\quad 0-5$. https://doi.org/10.1080/14681811.201 5.1100599 
Komisi Nasional Perlindungan Anak. (2016). Catatan Akhir Tahun Komisi Nasional Perlindungan Anak 2016. Jakarta.

Komisi Nasional Perlindungan Anak. (2017). Catatan Kritis Akhir Tahun 2017 dan Prediksi Situasi Anak Indonesia 2018. Jakarta.

Kristiana, S., Jamaris, M., \& Sumantri, M. S. (2018). Utilization of Demonstration Methods as Sex Education in Early Childhood. International Journal of Multidiciplinary and Current Research, 6(2006), 811-814. Retrieved from http://ijmcr.com

Martin, J., Riazi, H., Firoozi, A., \& Nasiri, M. (2018). A sex education programme for mothers in Iran : Does preschool children' s sex education influence mothers ' knowledge and attitudes? Sex Education, 1811, 1-12. https://doi.org/10.1080/14681811.201 8.1428547

Nadar, W. (2017). Persepsi Orangtua Mengenai Pendidikan Seks Untuk Anak Usia Dini. Ya Bunayya: Jurnal Pendidikan Anak Usia Dini, 77-90.

Probosiwi, R., \& Bahransyaf, D. (2015). Pedofilia dan Kekerasan Seksual: Masalah dan Perlindungan Terhadap Anak. Sosio Informa, 1(1), 29-40.

Rilianti, A. P., \& Ima, A. (2011). Play Study: Educational Game sebagai Media Belajar Pendidikan Seks Bagi Anak Sekolah Dasar, 1-10.

Rowntree, D. (1994). Preparing Materials for Open, Distance and Flexible Learning. An Action Guide for Teachers and Trainers. London: Kogan Page.

Rudolph, J., \& Zimmer-Gembeck, M. J. (2018). Parents as protectors: A qualitative study of parents' views on child sexual abuse prevention. Child Abuse \& Neglect, 85, 28-38. https://doi.org/10.1016/j.chiabu.2018. 08.016

Sciaraffa, M., \& Randolph, T. (2011). "You Want Me to Talk to Children about What?" Responding to the Subject of Sexuality Development in Young Children. Young Children. Retrieved from

https://manchester.idm.oclc.org/login ?url=http://search.proquest.com/docvi ew $/ 1011397287$ ? accountid $=12253 \% 0$

Ahttp://man-

fe.hosted.exlibrisgroup.com/openurl/4 4MAN/44MAN_services_page?url_v er $=$ Z39.88-

2004\&rft_val_fmt=journal\&genre=un known\&sid=ProQ:ProQ\%3Aeducat

Sugiasih, I. (2011). Need Assessment Mengenai Pemberian Pendidikan Seksual Yang Dilakukan Ibu Untuk Anak Usia 3 - 5 Tahun Need Assessment of Sexual Education By Mother. Jurnal Psikologi Proyeksi, 6(1), 71-81. Retrieved from research.unissula.ac.id

Tampubolon, G. N., Nurani, Y., \& Meilani, R. S. M. (2019). Parents ' Knowledge and Attitude Towards Sex Education on Children Aged 0-6 Years Old.

Turnbull, T., Wersch, A. van, \& Schaik, P. van. (2008). A Review of Parental Involvement in Sex Education: The Role for Effective Communication in British Families. Health Education Journal, 67(3), 182-195. https://doi.org/10.1177/00178969080 94636

UNESCO. (2009). International Technical Guidance on Sexuality Education: An evidence-informed approach for schools, teachers and health educators. UNESCO (Vol. I). Paris. Retrieved from https://www.jstor.org/stable/pdf/2568 1359.pdf?refreqid=excelsior\%3A109 ae30a0dd73e9e60b7de2bd71feb4b 
UNESCO. (2018). International technical guidance on sexuality education: An evidence-informed approach. the United Nations Educational, Scientific and Cultural Organization (Vol.

https://doi.org/10.1097/HCR.0b013e3 $1827 \mathrm{e} 14 \mathrm{da}$

Walsh, K., \& Brandon, L. (2012). Their Children's First Educators: Parents' Views About Child Sexual Abuse Prevention Education. Journal of Child and Family Studies, 21(5), 734-746.

https://doi.org/10.1007/s10826-0119526-4

Wurtele, S. K., Moreno, T., \& Kenny, M. C. (2008). Evaluation of a Sexual Abuse Prevention Workshop for Parents of Young Children. Journal of Child \& Adolescent Trauma, 1(4), 331-340.

https://doi.org/10.1080/19361520802 505768

Xie, Q. W., Qiao, D. P., \& Wang, X. L. (2016). Parent-Involved Prevention of Child Sexual Abuse: A Qualitative Exploration of Parents' Perceptions and Practices in Beijing. Journal of Child and Family Studies, 25(3), 999-1010.

https://doi.org/10.1007/s10826-0150277-5

Zakiyah, R. (2016). Tabu, Hambatan Budaya Pendidikan Seksualitas Dini Pada Anak di Kota Dumai. Journal of Community Medicine and Public Health, 32(9).

Zhina, C. (2013). A Review of Sex Education for Preschool Children in Mainland China from 1992 to 2012. International Review of Social Sciences and Humanities, 5(2), 1218. 